\title{
Penerapan Model Pembelajaran Kooperatif Tipe STAD untuk Meningkatkan Minat Belajar Peserta Didik Kelas XI IPA. 1 SMA Negeri 1 Sa'dan Balusu terhadap Mata Pelajaran Kimia
}

\section{The Implementation of STAD Type Cooperative Learning Student to Improve the Learning Interest of Student Class XI IPA. 1 at SMA Negeri 1 Sa'dan Balusu on Chemistry Matter}

\author{
Andarias Lampin Darandang \\ SMA Negeri 1 Sa'dan Balusu, Kabupaten Toraja Utara \\ Email:parmenasobaja5@gmail.com
}

\begin{abstract}
ABSTRAK
Pengajaran Kimia di SMA Negeri 1 Sa'dan Balusu sampai saat ini belum bisa dikatakan berhasil. Kenyataan ini didukung oleh ketuntasan belajar peserta didik masih jauh dari yang diharapkan. Adanya sebagian guru kimia yang di dalam mengajar hanya dengan metode ceramah tanpa melibatkan peserta didik untuk aktif di dalamnya, semakin menambah kecenderungan peserta didik bahwa kimia itu membosankan. Dengan memperhatikan kesenjangan yang ada dan untuk mendapatkan pemecahan dari permasalahan tersebut, maka dilakukan Penelitian Tindakan Kelas (PTK) dengan metode pembelajaran kooperatif tipe STAD dalam pembelajaran konsep Termokimia. PTK ini dilakukan dalam dua siklus pembelajaran, dimana masing-masing siklus terdiri dari 1. Perencanaan; 2. Pelaksanaan; 3. Pengamatan; 4. Refleksi. Subyek penelitian ini adalah peserta didik kelas XI IPA. 1 SMA Negeri 1 Sa'dan Balusu. Hasil penelitian ini menunjukkan bahwa terdapat peningkatan minat belajar peserta didik.
\end{abstract}

Kata kunci: Kooperatif, Minat Belajar, Chemistry

\begin{abstract}
Chemistry Teaching at SMA Negeri 1 Sa'dan Balusu has not been successful yet. This fact is supported by the completeness of student learning is still far from expected. The existence of some chemistry teachers who teach only speaking method without the involvement of students to be active in it, increasing the student's tendency that chemistry is boring. By considering the existing gap and to get the solution of the problem, the Classroom Action Research with STAD type cooperative learning method in learning Thermochemical concept was done. This Classroom Action Research was conducted in two learning cycles, each cycle consisting of 1 . Planning; 2. Implementation; 3. Observations; 4. Reflection. The subjects of this study were students of class XI IPA. 1 at SMA Negeri 1 Sa'dan Balusu. The results of this study indicate that there was enhancement of student learning interest.
\end{abstract}

Keywords: Cooperative, Learning interest, Chemistry 


\section{PENDAHULUAN}

Pengajaran Kimia di SMA Negeri 1 Sa'dan Balusu sampai saat ini belum bisa dikatakan berhasil. Kenyataan ini didukung oleh ketuntasan belajar peserta didik masih jauh dari yang diharapkan. Berdasarkan kenyataan yang ada, tidak sedikit peserta didik di SMA ini yang menganggap Kimia sebagai mata pelajaran yang kadang membingungkan. Untuk itu perlu diupayakan bagaimana caranya agar pelajaran kimia dapat menarik minat peserta didik untuk mempelajarinya sehingga diharapkan dalam proses pembelajarannya dapat mencapai ketuntasan yang diharapkan.

Model kooperatif tipe STAD

(Student Teams Achievement Divisions) lebih cocok digunakan dalam mengajarkan tujuan pembelajaran yang dirumuskan dengan satu jawaban benar seperti perhitungan dan penerapan bercirikan matematika, penggunaan bahasa dan mekanika, keterampilan membaca peta, geografi, dan fakta-fakta konsep IPA. Dalam pembelajaran kooperatif tipe STAD ini peserta didik dibagi beberapa kelompok dan tiap kelompok mempunyai 4 (empat) atau 5 (lima) anggota yang dipilih berdasarkan keheterogenan menurut jenis kelamin, suku, maupun intelektual. Guru menyajikan pelajaran dan peserta didik bekerja dalam kelompok mereka untuk memastikan bahwa seluruh anggota kelompok telah memahami pelajaran tersebut. Pada akhir pembelajaran diadakan evaluasi (kuis) dimana peserta didik bekerja secara individual dan tidak lagi bekerja secara kelompok tetapi nilai yang diperoleh merupakan nilai rata-rata kelompok. Kelompok peserta didik yang mendapat nilai ratarata tertinggi mendapatkan penghargaan atas nama kelompok itu (Wawang, 2000).

Oleh karena itu, dengan memperhatikan kesenjangan yang ada serta di dukung oleh penelitian sebelumnya, maka peneliti tertarik untuk mengadakan Penelitian Tindakan Kelas untuk meningkatkan minat belajar peserta didik terhadap pembelajaran kimia melalui penerapan model pembelajaran koperatif tipe STAD di SMA Negeri 1 Sa'dan Balusu.

\section{METODE PENELITIAN}

Jenis penelitian yang digunakan dalam penelitian ini adalah PTK yang bersifat kolaboratif yaitu dengan melibatkan Kepala Sekolah, Guru Kimia yang secara formal bertugas di sekolah yang bersangkutan sebagai pengamat. Penelitian ini juga berusaha mengkaji, merefleksikan secara kritis terhadap suatu rencana pembelajaran terhadap kinerja guru, interaksi guru dan peserta didik, serta interaksi antara peserta didik di dalam kelas. Metode Penelitian Tindakan Kelas ini menekankan pada suatu kajian yang benar-benar dari situasi alamiah di kelas.

\section{A. Setting Penelitian}

Penelitian ini dilaksanakan di SMA Negeri 1 Sa'dan Balusu Kabupaten Toraja Utara ,yang berada di Kelurahan Sa'dan Malimbong Kecamatan Sa'dan. Peserta didik yang masuk ke sekolah ini rata-rata 
mempunyai nilai yang tidak terlalu tinggi. Jika pendaftaran peserta didik baru dimulai biasanya sekolah ini masih menunggu limpahan dari kota atau sekolah lainnya. Adapun kelas yang diteliti dalam PTK ini adalah kelas XI IPA. 1 dengan jumlah peserta didik sebanyak 32 (tiga puluh dua) orang terdiri dari 12 (dua belas) peserta didik putra dan 20 (dua paluh ) peserta didik putri.

\section{B. Persiapan Penelitian}

Dalam persiapan penelitian ini, langkah-langkah yang dilakukan peneliti antara lain observasi pra penelitian untuk mengetahui minat awal peserta didik terhadap materi pelajaran kimia, dan prestasi belajar peserta didik.

Selanjutnya mempersiapkan rencana pembelajaran, lembar kerja yang merupakan lembar panduan bagi peserta didik untuk berpikir kritis dalam memecahkan masalah, angket, serta lembar observasi.

$$
\text { Dalam penelitian ini }
$$

pembagian kelompok dilakukan dengan cara berikut:

1. Peserta didik diurutkan dari atas ke bawah berdasarkan nilai ulangan harian struktur atom.

2. Dari urutan tersebut, kemudian di bagi dalam delapan kelompok dimana masing-masing kelompok beranggotakan 4 (empat) orang.

3. Diupayakan dalam kelompok merata dalam hal kemampuan, jenis kelamin, suku, dan agamanya.

\section{Siklus Penelitian}

Penelitian ini dibagi menjadi 2 (dua) siklus yang, terdiri dari beberapa langkah berikut:

1. Perencanaan, yaitu menyusun rumusan masalah, menentukan tujuan dan metode penelitian serta membuat rencana tindakan.

2. Tindakan, dilakukan oleh peneliti sebagai upaya perubahan yang dilakukan.

3. Pengamtan/Observasi, dilakukan dengan mengamati hasil atau dampak dari tindakan yang dilakukan terhadap peserta didik.

4. Refleksi, pada tahap ini peneliti mengkaji dan mempertimbangkan hasil atau dampak dari tindakan yang dilakukan.

\section{Pembuatan Instrumen}

Untuk mengumpulkan data penelitian digunakan instrumen penelitian antara lain:

1. Angket, digunakan untuk memperoleh data tentang minat peserta didik terhadap pelajaran kimia.

2. Lembar observasi, digunakan untuk memperoleh data tentang proses pembelajaran yang dilaksanakan baik bagi guru maupun peserta didik.

3. Angket tanggapan peserta didik, digunakan untuk mengetahui tanggapan peserta didik tentang kegiatan pembelajaran yang sudah dilakukan.

4. Alat evaluasi, digunakan untuk memperoleh data tentang tingkat keberhasilan peserta didik. 
HASIL DAN PEMBAHASAN

Hasil penelitian ini dapat dikemukakan dalam dua siklus.

\section{A. Siklus I}

\section{Perencanaan}

Pada bagian ini peserta didik dikenalkan dengan model pembelajaran kooperatif tipe STAD agar nantinya pada pelaksanaan penelitian yang sesungguhnya peserta didik tidak merasa canggung lagi.

Peserta didik dibiasakan untuk bergabung dengan kelompoknya serta bekerja sama dengan anggota kelompoknya. Kemudian peneliti memberikan angket respon peserta didik terhadap pelajaran kimia yang antara lain berisi alasan mereka sekolah di SMA ini, pelajaran yang disukai/tidak disukai, tanggapan mereka tentang pelajaran kimia dan harapannya, serta nilai kimia yang telah didapatkannya selama ini memuaskan/tidak.

Kemudian guru menyiapkan tugas rumah yang akan diberikan kepada peserta didik termasuk menyiapkan LKS untuk praktikum sederhana yang akan dilaksanakan di kelas nanti serta bahan apa saja yang harus mereka bawa dari rumah oleh masing-masing kelompok dan guru menyiapkan soal ulangan harian pertama.

\section{Pelaksanaan}

Guru menyampaikan tujuan pembelajaran yang akan dicapai serta memberi motivasi kepada peserta didik. Kemudian guru memberikan beberapa soal kepada peserta didik untuk mengetahui kemampuan awal peserta didik. Berikutnya guru membentuk kelompok heterogen yaitu berdasarkan kemampuan serta jenis kelamin. Kemudian setelah peserta didik bergabung dengan kelompok masing-masing, guru membagikan lembar kerja yang digunakan untuk praktikum dan bahan diskusi kelompok.

\section{Pengamatan}

Berdasarkan kegiatan yang sudah dilaksanakan, Peserta didik merasa senang ternyata banyak bahan di sekitar mereka yang dapat digunakan untuk percobaan walaupun tidak harus dilakukan di laboratorium.

Setelah dilaksanakan validasi jawaban dari permasalahan yang ada di LKS peserta didik menjadi lebih paham sehingga ketika guru menyampaikan besok diadakan kuis/ulangan mereka menjawab Ya. Dari hasil ulangan yang dilaksanakan hasilnya diperingkat secara kelompok.

Pada siklus I terbaik pertama adalah kelompok Emas, terbaik kedua kelompok perak, dan terbaik ketiga adalah kelompok karbon.

\section{Refleksi}

Ada beberapa hal yang dapat direfleksikan dari hasil penelitian siklus I antara lain :

1. Peserta didik kurang terampil dalam melaksanakan praktikum.

2. Hasil ulangan harian ternyata masih banyak peserta didik yang belum memenuhi ketuntasan belajar. Dari 32 orang peserta didik baru 20 peserta didik yang mengalami ketuntasan dengan SKBM Kimia 60. 


\section{B. Siklus II \\ 1. Perencanaan}

Dengan melihat hasil refleksi dari Siklus I maka pada Siklus II ini peserta didik lebih banyak akan dilatih untuk kegiatan praktikum serta peserta didik banyak diaktifkan dalam kegiatan kelompoknya. Pada siklus kedua ini tetap diadakan tes awal untuk mengetahui kesiapan dan pemahaman peserta didik tentang materi yang akan dipelajarinya nanti. Kemudian disiapkan juga soal untuk ulangan harian yang kedua.

\section{Pelaksanaan}

Pada pelaksanaan kegiatan belajar mengajar di siklus yang kedua guru menyebutkan tujuan pembelajaran serta memotivasi peserta didik agar lebih giat dan aktif dalam kegiatan belajarnya. Setelah itu diadakan tes awal untuk mengetahui pengetahuan peserta didik tentang materi yang telah dirangkumnya.

Setelah kegiatan selesai, masing-masing kelompok secara bergantian menjawab pertanyaan yang ada di LKSnya kemudian guru melakukan validasi jawaban.

Pada pertemuan berikutnya setelah peserta didik melakukan praktikum di laboratorium, peserta didik tetap bekerja pada masingmasing kelompoknya untuk menuntaskan materi yang ada pada sub pokok bahasan kedua yang berupa latihan soal. Setelah peserta didik selesai mengerjakan LKSnya maka secara bergiliran masing-masing kelompok mempresentasikan hasil pekerjaannya kemudian guru melakukan validasi jawaban.
Kemudian pada pertemuan berikutnya diadakan Ulangan Harian kedua dan diberi penghargaan untuk kelompok yang memperoleh rata-rata nilai terbaik. Penghargaan kelompok didasarkan pada hasil ulangan harian kedua, Terbaik pertama didapatkan oleh kelompok Oksigen, terbaik kedua kelompok Hidrogen dan kelompok Besi serta terbaik ketiga kelompok Zink.

\section{Pengamatan}

Secara umum ketrampilan peserta didik dalam melaksanakan kegiatan praktikum ada peningkatan. Dalam bekerjasama dengan kelompoknya peserta didik sudah mulai banyak aktif terlibat, jika dibanding siklus pertama. Untuk pengelolaan proses belajar mengajarnya guru secara umum adalah baik

\section{Refleksi}

Dari perlakuan yang ada ternyata ada peningkatan kemampuan peserta didik yang dalam arti peserta didik lebih berani bertanya jika mengalami kesulitan. Untuk hasil ulangan harian ada peningkatan ketuntasan peserta didik. Dari 32 peserta didik yang mengalami ketuntasan yakni 24 orang peserta didik.

\section{KESIMPULAN DAN SARAN}

\section{A. Kesimpulan}

Berdasarkan dari hasil penelitian yang dilakukan dapat diperoleh kesimpulan bahwa waktu terbesar guru digunakan untuk membimbing peserta didik. Sedangkan 
Penerapan Model Pembelajaran Kooperatif Tipe STAD untuk Meningkatkan Minat Belajar Peserta Didik Kelas XI IPA. I SMA Negeri I Sa'dan Balusu terhadap Mata Pelajaran Kimia

sebagian besar aktivitas peserta didik digunakan untuk bekerja dalam kelompoknya, dan kegiatan secara umum berpusat pada peserta didik sehingga suasana kelas menjadi hidup. Dengan demikian, penggunaan model pembelajaran kooperatif tipe STAD dapat meningkatkan minat belajar peserta didik.

\section{B. Saran}

Siklus penelitian perlu ditambah sehingga dapat diperoleh hasil pengamatan yang lebih baik lagi. Selanjutnya, dalam melaksanakan PTK wawasan peneliti perlu diperluas sehingga kegiatan penelitian dapat berjalan dengan lancar termasuk perlunya kolaboratif dengan rekanan yang memang ahli dalam bidangnya.

\section{DAFTAR PUSTAKA}

Nurhadi, 2004, Pembelajaran Kontekstual dan Penerapannya dalam KBK, Malang: UMPRESS.

Usman, MU, 1996, Menjadi Guru Profesional, Bandung: Remaja Rosda Karya.

Wawan Hoetawarman, 2000, Penggunaan Model Pembelajaran Koopertif Tipe STAD untuk meningkatkan Ketrampilan Proses Siswa pada Pembelajaran Konsep Kesetimbangan Kimia di Kelas II Cawu I SMU Negeri 1 Jombang. 